\title{
Experience of pain in a patient with BRONJ
}

This article was published in the following Dove Press journal:

Clinical Interventions in Aging

6 July 2015

Number of times this article has been viewed

\author{
Ömer Bakal \\ Ali Alper Tirnava \\ Huseyin Sen \\ Department of Anesthesiology \\ and Reanimation, GATA Haydarpasa \\ Training Hospital, Istanbul, Turkey
}

Correspondence: Ömer Bakal Department of Anesthesia and Reanimation, GATA Haydarpasa Training Hospital, Tibbiye caddesi, Uskudar, 34668 Istanbul, Turkey Tel +90545 4II 7648

Fax +90216542 2020

Email omerbakal@yahoo.com

\section{Dear editor}

We read with great interest the case report concerning a patient with bisphosphonaterelated osteonecrosis of the jaw (BRONJ) reported by Manzon et al. ${ }^{1}$ In this report, they describe BRONJ complicated by a temporal abscess in an elderly woman with rheumatoid arthritis. We congratulate Manzon et al on their successful treatment of this patient. They briefly discussed the evidence for the relationship between bisphosphonate therapy and BRONJ, and the effects of co-occurring factors, such as rheumatoid arthritis, dental surgery, and concomitant corticosteroid therapy.

We would also like to add our experience of treating pain in a patient with BRONJ. A 71-year-old woman weighing $50 \mathrm{~kg}$ was referred to our hospital in February 2015 with difficulty opening her mouth, trismus, fever, headache, and severe pain. The patient's past medical history was relevant for rheumatoid arthritis, treated from 1995 with methotrexate, leflunomide, daily oral calcium, and vitamin D3 for 20 years and oral prednisone $0.1 \mathrm{mg} / \mathrm{kg}$ was added for the last 10 years. After a vertebral fracture caused by severe osteoporosis, the patient started treatment with alendronate sodium $10 \mathrm{mg}$ daily in tablet form.

In March 2014, the patient underwent a lower right first molar extraction following development of an abscess. The patient had a noticeable right-sided mandibular abscess with a right-sided soft temporal swelling and redness, and severe pain on mouth opening. Oral examination revealed an abscess in the posterior mandible, in the area of the recent extraction, with pus leaking from the previous surgical site. Infection and swelling was extending distally to the lower right first molar.

We examined the patient and detected no laboratory abnormalities in liver and kidney function. She reported that her pain persisted throughout the day and that she was unable to eat due to pain. We ordered paracetamol $10 \mathrm{mg} / \mathrm{kg}$ intravenous and tramadol $1 \mathrm{mg} / \mathrm{kg}$ intravenously, four times daily. At the end of the 1st day, her pain resolved and she was able to return to her daily routines.

The etiopathogenic mechanism of BRONJ remains unclear, and no universally accepted therapeutic protocol is known to eradicate it; however, the treatment goal should be focused on eliminating pain and preventing progression to bone infection and necrosis. ${ }^{2}$ Rheumatoid arthritis is considered an important contributing factor for BRONJ, even though the relationship between the two diseases is not yet fully understood. Bone tissue damage and bone loss are typical features of rheumatoid arthritis. ${ }^{3}$ Osteonecrosis may develop for local or multifocal reasons. Malnutrition and general malaise can be found due to pain in elderly patients with BRONJ. These patients must be carefully evaluated, and weak narcotics like tramadol can be used safely.

\section{Disclosure}

The authors report no conflict of interest in this communication. 


\section{References}

1. Manzon L, Ettorre E, Viscogliosi G, et al. Bisphosphonate therapy and osteonecrosis of the jaw complicated with a temporal abscess in an elderly woman with rheumatoid arthritis: a case report. Clin Interv Aging. 2014;9:1409-1413.
2. Bocanegra-Perez S, Vicente-Barrero M, Knezevic M, et al. Use of platelet-rich plasma in the treatment of bisphosphonate-related osteonecrosis of the jaw. Int J Oral Maxillofac Surg. 2012;41:1410-1415.

3. Breuil V, Euller-Ziegler L. Bisphosphonate therapy in rheumatoid arthritis. Joint Bone Spine. 2006;73:349-354. 


\section{Authors' reply \\ Licia Manzon' \\ Evaristo Ettorre' \\ Giovanni Viscogliosi' \\ Stefano Ippoliti' \\ Fabio Filiaci ${ }^{2}$ \\ Claudio Ungari \\ Giovanni Fratto' \\ Alessandro Agrillo 2 \\ 'Department of Cardiovascular, Respiratory, Nephrologic, Anesthesiologic and Geriatric Sciences, ${ }^{2}$ Department of Odontology and Maxillofacial Surgery, Sapienza University, Rome, Italy}

Correspondence: Giovanni Viscogliosi

Department of Cardiovascular, Respiratory, Nephrologic,

Anesthesiologic and Geriatric Sciences, Sapienza University,

Viale del Policlinico 155, Rome 00185 , Italy

Tel +393398240918

Email giovanni.viscogliosi@libero.it

\section{Dear editor}

We are pleased to note that our case report has generated interest among readers. The case described in the letter by Bakal et al is very similar to the one we have previously described. ${ }^{1}$ They also document the case of a long-term sufferer of rheumatoid arthritis who developed bisphosphonate-related osteonecrosis of the jaw (BRONJ) after a dental extraction. Once again it is emphasized that orally administered bisphosphonates may increase the risk of BRONJ in patients on treatment with immunosuppressant agents such as corticosteroids or methotrexate. Both these cases allow us to hypothesize that routine dental procedures (ie, dental extractions) may trigger BRONJ in at-risk individuals.

The link between BRONJ and rheumatoid arthritis remains poorly understood. ${ }^{1-3}$ We hypothesize that both etiological and treatment-related factors are involved. ${ }^{2,3}$ Bone tissue damage and bone loss due to chronic inflammation are among the typical features of rheumatoid arthritis. Glucocorticoids and methotrexate, usually used as first-line therapy in patients with rheumatoid arthritis, and reduced mobility are also well known risk factors for osteoporosis in these patients. The current literature suffers from a lack of reports documenting the incidence of BRONJ in patients presenting with at-risk conditions or undergoing dental procedures. Clinical case-control investigations are needed to assess the incidence of BRONJ in such patients, in order to optimize management of the risk of BRONJ.

\section{Disclosure}

The authors report no conflicts of interest in relation to this communication.

\section{References}

1. Manzon L, Ettorre E, Viscogliosi G, et al. Bisphosphonate therapy and osteonecrosis of the jaw complicated with a temporal abscess in an elderly woman with rheumatoid arthritis: a case report. Clin Interv Aging. 2014;9:1409-1413.

2. Breuil V, Euller-Ziegler L. Bisphosphonate therapy in rheumatoid arthritis. Joint Bone Spine. 2006;73:349-354.

3. Haugeberg G, Orstavik RE, Uhlig T, Falch JA, Halse JI, Kvien TK. Bone loss in patients with rheumatoid arthritis: results from a populationbased cohort of 366 patients followed up for two years. Arthritis Rheum. 2002;46:1720-1728.

Dove Medical Press encourages responsible, free and frank academic debate. The content of the Clinical Interventions in Aging 'letters to the editor' section does not necessarily represent the views of Dove Medical Press, its officers, agents, employees, related entities or the Clinical Interventions in Aging editors. While all reasonable steps have been taken to confirm the content of each letter, Dove Medical Press accepts no liability in respect of the content of any letter, nor is it responsible for the content and accuracy of any letter to the editor.

\section{Publish your work in this journal}

Clinical Interventions in Aging is an international, peer-reviewed journal focusing on evidence-based reports on the value or lack thereof of treatments intended to prevent or delay the onset of maladaptive correlates of aging in human beings. This journal is indexed on PubMed Central, MedLine,
CAS, Scopus and the Elsevier Bibliographic databases. The manuscript management system is completely online and includes a very quick and fair peer-review system, which is all easy to use. Visit http://www.dovepress. com/testimonials.php to read real quotes from published authors. 